\title{
TREATMENT OF TRIGEMINAL NEURALGIA WITH LOW DOSES OF TOPIRAMATE
}

\author{
Renan Barros Domingues ${ }^{1,2,3}$, Gustavo Wruck Kuster ${ }^{1,2}$, \\ Camila Catherine Henriques Aquino ${ }^{3}$
}

\begin{abstract}
Topiramate was administered to eight patients with classical trigeminal neuralgia with or without previous symptomatic therapy with other antiepileptic drugs. The topiramate doses ranged from 50 to $100 \mathrm{mg}$ a day, according to the clinical response and the reported side effects. Three patients had complete symptoms remission, three reported moderate improvement, and the treatment was not effective in two. The most frequently registered side effects were dizziness, somnolence and weight loss. Topiramate can be considered an alternative treatment for patients with trigeminal neuralgia.
\end{abstract}

KEY WORDS: trigeminal neuralgia, topiramate, antiepileptic drugs.

\section{Tratamento da neuralgia do trigêmeo com baixas doses de topiramato}

RESUMO - Oito pacientes com neuralgia do trigêmeo, com ou sem tratamentos prévios com anticonvulsivantes, foram submetidos a tratamento com topiramato. As doses de topiramato variaram de 50 a $100 \mathrm{mg}$ ao dia, de acordo com a resposta clínica e com os efeitos colaterais relatados. Três pacientes obtiveram remissão completa, três relataram melhora parcial e o tratamento com topiramato foi ineficaz em dois pacientes. Os efeitos colaterais mais frequentemente citados foram tontura, sonolência e perda de peso. 0 topiramato pode ser considerado uma alternativa potencialmente eficaz para o tratamento de pacientes com neuralgia do trigêmeo.

PALAVRAS-CHAVE: neuralgia do trigêmio, topiramato, drogas anti-epilépticas.

Classical trigeminal neuralgia (TN) is a facial dolorous syndrome that occurs more often in the elderly, with annual incidence of 5.0 women and 2.7 men per 100,000 per year ${ }^{1}$. Because of the frequency of attacks and their severity, chronic preventive therapy is necessary. However, the treatment of this disorder remains a therapeutic challenge because clinical treatment frequently fails ${ }^{2,3}$.

Some antiepileptic drugs are effective in improving TN symptoms. Carbamazepine is the most frequently prescribed of them. Recently, gabapentin has demonstrated analgesic effect for the treatment of TN and others neuropathic pain syndromes ${ }^{4-7}$. Topiramate is a new antiepileptic drug that blocks sodium channels, enhances GABA activity by interacting with a non-benzodiazepine site on GABA A receptors, and selectively blocks AMPA/kainite glutamate receptors ${ }^{8}$. Some studies have demonstrated that topiramate can be considered an alternative treatment for classical and symptomatic trigeminal neuralgia ${ }^{9,10}$.

We report our experience on the use of topiramate for trigeminal neuralgia.

\section{METHOD}

Eight patients attended in the EMESCAM Headache Clinic were included in this study. All of them were diagnosed as having classical trigeminal neuralgia according to the International Classification of Headache Disorders ${ }^{11}$. Previous treatments for TN were recorded. All of them reported frequent and intense pain episodes when topiramate was started. The initial dose was $25 \mathrm{mg}$ once a day. 1Departamento de Patologia, Escola Superior de Ciências da Santa Casa de Misericórdia de Vitória (EMESCAM), Vitória ES, Brazil;
${ }^{2}$ Centro Integrado de Neurologia, Hospital Meridional, Vitória ES, Brazil; ${ }^{3}$ Ambulatório de Cefaléias, EMESCAM, Vitória ES, Brazil.

Received 16 January 2007, received in final form 19 April 2007. Accepted 6 June 2007.

Dr. Renan Barros Domingues - Avenida Nossa Senhora da Penha 699 / sala 709 - 29055-131 Vitória ES - Brasil. E-mail: renan-domingues @uol.com.br 
The patients were evaluated weekly. If pain was still reported and if there was not intolerance to the medication topiramate was increased $25 \mathrm{mg}$ every week to a maximum of $100 \mathrm{mg}$ a day. The patients were followed during eight weeks. The relief of the symptoms was graduated into four levels according to the report of the patient: absent, little, moderate, and complete, and was recorded every visit and at the end of the follow-up time. All the topiramate side effects were registered. This study was approved by the local ethic committee.

\section{RESULTS}

The mean age was $62 \pm 14.4$ years. Five patients were female. Two patients were already under treatment for trigeminal neuralgia. One of them with carbamazepine (1200 mg/day) and the other was receiving carbamazepine (600 mg/day), baclofen ( $30 \mathrm{mg} /$ day), and amytriptiline ( $25 \mathrm{mg} /$ day). None of these two patients had good clinical response with these drugs. The time of disease ranged from one week to thirty years.

The topiramate maximum dose was $100 \mathrm{mg}$ ( 2 patients), $75 \mathrm{mg}$ (1 patient), and $50 \mathrm{mg}$ (5 patients). Seven of the patients have completed the eight weeks follow up time with topiramate. One of them has interrupted the treatment due to intolerance to topiramate. A complete remission of the pain attacks was obtained in 3 patients using topiramate $50 \mathrm{mg} /$ day. A moderate improvement was reported by 3 patients, one with 50 , one with 75 , and one with $100 \mathrm{mg}$ a day of topiramate. The patient with moderate improvement with $50 \mathrm{mg}$ of topiramate has interrupted the medication during the third week of treatment due to intolerance. At that time this patient referred moderate improvement with topiramate. The patient with moderate improvement with $75 \mathrm{mg}$ did not tolerate $100 \mathrm{mg}$ a day and returned to $75 \mathrm{mg}$ a day. The patient with moderate improvement with $100 \mathrm{mg}$ of topiramate was previously using carbamazepine $1200 \mathrm{mg} /$ day and this drug was not interrupted during the follow up time. Two patients reported little improvement with $100 \mathrm{mg} /$ day of topiramate. One of these patients was already receiving carbamazepine $600 \mathrm{mg} /$ day, baclofen $30 \mathrm{mg} /$ day, and amytriptiline $25 \mathrm{mg} /$ day. Among the six patients that used only topiramate, three had complete remission, two had moderate improvement but one of them did not tolerate the two months treatment, and one had little improvement. Among the two patients in whom topiramate was added to other drugs, one had moderate and one had little improvement.

Four patients referred side effects of topiramate. Three patients referred dizziness and sedation. One of these patients interrupted topiramate due to these symptoms. One patient had cognitive impairment, one had fatigue, one had nausea, one had blurred vision, and one complained weight loss. Except for the patient that interrupted topiramate treatment all the other reported that side effects disappeared in the second month of treatment.

\section{DISCUSSION}

Carbamazepine is usually the first-line therapy for TN. Gabapentin also has showed to be effective in the treatment of this disease. The introduction of newer antiepileptic drugs in the spectrum of therapeutic options for TN may be helpful since not all patients obtain complete remission of pain with traditional drugs and also because patients may show intolerance with some antiepileptic drugs and not with others.

Six patients $(75 \%)$ in our study had complete or moderate improvement of TN symptoms using topiramate, five of them (62.5\%) have completed the two months follow up. One of these patients was already using carbamazepine without clinical response with this drug. After $100 \mathrm{mg}$ a day of topiramate this patient referred improvement although his clinical response was considered moderate. Two patients reported only a little clinical improvement; both of them with $100 \mathrm{mg}$ a day of topiramate. One of them was already using other drugs and reported just a little improvement after topiramate. Therefore the use of topiramate alone was efficient and well tolerated in most of the patients and the association of topiramate with other drugs brought moderate relief in one and little relief in another patient.

The topiramate doses we used in this study were lower than the doses used in a previous study with topiramate for $\mathrm{TN}^{\mathrm{N}}$ treatment ${ }^{9}$. It is also interesting that all the three patients in our study with complete clinical remission used only $50 \mathrm{mg}$ a day of topiramate. It suggests that lower topiramate doses can be initially tried for TN and that the improvement with topiramate treatment may be seen in the beginning of the treatment.

This study has limitations. First, the group of patients was not homogenous in terms of time of disease and previous treatments. Second, the study was not controlled. Third, the follow up time was short. However, considering that trigeminal neuralgia is not a common disorder and that there are not many controlled and comparative studies in TN, we believe our data are relevant. Our data strength the hypothesis 
that topiramate can be considered a relatively safe drug that is potentially effective in the treatment of TN. Also our data suggest that small doses than previously tried in other studies can be used and the progressive increasing doses schedule may be efficient and may enhance tolerability to this drug.

\section{REFERENCES}

1. Turp JC, Gobetti JP. Trigeminal neuralgia-an update. Compend Cont Educ Dent 2000;21:279-292.

2. Taylor JC, Brauer S, Espir ML. Long-term treatment of trigeminal neuralgia with carbamazepine. Postgrad Med J 1981;57:16-18.

3. Canavaro S, Bonicazi V. Drug therapy of trigeminal neuralgia. Expert Rev Neurother 2006;6:429-440.
4. Cheshire WP Jr. Defining the role for gabapentin in the treatment of trigeminal neuralgia: a retrospective study. J Pain 2002;3:137-142.

5. Khan O. Gabapentin relives trigeminal neuralgia im multiple sclerosis. Neurology 1998;51:611-614.

6. Gidal BE. New and emerging treatment options for neuropathic pain. Am J Manag Care 2006;12(Suppl 9):S269-S278.

7. Todd D, Rozen MD. Antiepileptic drugs in the management of cluster headache and trigeminal neuralgia. Headache 2001;41(Suppl 1):S25S32. 8 Scheneiderman JH. Topiramate: pharmacokinetics and pharmacodinamics. Can J Neurol Sci 1998;25:3-5

9. Gilron I, Booher SL, Rowan JS, Max MB. Topiramate in trigeminal neuralgia: a randomized, placebo-controlled multiple crossover pilot study. Clin Neuropharmacol 2001;24:109-212.

10. Zvartaui-Hind M, Din MU, Gilani A, Lisak RP, Khan OA. Topiramate relieves refractory trigeminal neuralgia in MS patients. Neurology 2000;55:1587-1588.

11. Headache Classification Subcommitte of the International Headache Society. The international classification of headache disorders, 2.Ed. Cephalalgia 2004;24:1-160. 